\title{
Increase of productivity in small and medium- sized enterprises in Thailand
}

\author{
Pisit Potjanajaruwit, ${ }^{1, *}$ \\ ${ }^{1}$ FMS, Suan Sunandha Rajabhat University, 1 U-Thong Nok rd, 10200, Dusit, Bangkok, Thailand
}

\begin{abstract}
The purpose of this research was to study the association of human resource management and the increase of productivity of small and medium-sized enterprises in Thailand. The study was conducted in the sample group which included owners of 269 small and medium-sized enterprises in Thailand using questionnaires. The statistics used in the research were frequency, percentage, mean, standard deviation, One-way ANOVA, multiple correlation analysis, and multiple regression analysis. The research revealed that the association between human resource management and productivity increase of small and medium enterprises in Thailand was found at a relatively high level. When testing the impact of human resource management on productivity, it was found that human resource management in the areas of recruitment, rewarding, and the protection and maintenance of human resources have an impact on productivity increase of small and medium-sized enterprises in Thailand.
\end{abstract}

\section{Introduction}

Amidst the changing economic conditions in this region and in the world, competitions become borderless and more intense. Such changes inevitably have a profound effect on Thailand's industrial development because the national economy has a high level of interactions with foreign countries, both in production and trade, as well as having to compete with countries that have an economic development of a comparable level or inferior to Thailand. Therefore, the Office of National Economic and Social Development Board has policies on the development of management of various resources of the country to maximize the nation's benefits - especially focusing on human development, which is an important factor of success in operations, resulting in attitudes, thinking methods and practices that will increase the country's competitive potential. As for the administrative resources, it is commonly known that they include man, money, material, and management which are often referred to as 4Ms. The "man" or people in particular is said to be the most valuable resource in in an organization, because people can use their knowledge and skills to transform other organizational resources into products and services, and create profits and other valuables for the organization $[1,2]$ Aside from "people", another way to increase the potential and competitiveness is to increase "productivity", which is another tool that

*Corresponding author: pisit.po@ssru.ac.th 
can help Thailand overcome the economic crisis. By increasing the ability to compete in organizations - such as industrial factories, state enterprises, offices, and institutions, as well as increasing productivity at the family and individual levels, it will enhance the competitiveness and bring the nation a more competitive advantage in the world market. It will also benefit in the progress of national economic development and ultimately the wellbeing of every member of the nation. Improving productivity is not a goal in itself, it is a method to achieve the ultimate goal, which is to raise the standard of living and to improve the quality of life of people in the country [3, 4].

Small and medium-sized enterprises in Thailand are considered as one of the key businesses that will lead development according to the aforementioned concept. Therefore, there should be development and studies of various ideas, especially the ones regarding increasing productivity and human resource management, which help to get adequate information for planning of human resource management and increase of productivity. In order to increase capacity to compete of small and medium-sized enterprises, it can be done by using a productivity improvement program which is another way to improve competitiveness for small and medium-sized enterprises in the long run. It creates concepts for executives and employees to understand about the importance and necessity of increasing productivity in the organization or productivity awareness. It helps setting a system to increase productivity for the organization to be able to produce high quality products that meet the needs of customers through low cost production processes and deliver products on time. According to the reasons mentioned above, it can be seen that the increase of productivity of small and medium enterprises in Thailand is very necessary. Thus, this study aimed to explore the association between human resource management and the increase of productivity of small and medium-sized enterprises in Thailand [5].

\section{Methodology}

In conducting research on increasing productivity of small and medium-sized enterprises in Thailand in this study, the methodology was set in accordance with the following topics: 1 . population and sample group, 2. research tools, 3. quality assurance of research tools, 4. data collection, and 5. data analysis and statistics.

\subsection{Determining of population and sample group}

Population of this research was small and medium-sized enterprises in Thailand that had been registered with the Department of Industrial Works, of which there were 14,557 in total. Sample group used in the research was 375 people from small and medium enterprises in the northern región, which were chosen by using [6].

Table 1. Number of population and sample group of small and medium-sized enterprises in Thailand as classified by business type.

\begin{tabular}{|c|c|c|c|}
\hline Types of Business & $\begin{array}{c}\text { Numbers of } \\
\text { population (people) }\end{array}$ & $\begin{array}{c}\text { Numbers of sample } \\
\text { group (people) }\end{array}$ & $\begin{array}{c}\text { Numbers of } \\
\text { respondents (people) }\end{array}$ \\
\hline 1.Manufacturing Business & 3.173 & 82 & 49 \\
2.Trading Business & 7.768 & 200 & 164 \\
3.Service Business & 3.616 & 93 & 56 \\
\hline Total & 14.557 & 375 & 269 \\
\hline
\end{tabular}


In this study, data was collected by sending 375 questionnaires to entrepreneurs of small and medium enterprises in the northern region of Thailand by postal service. There was also a reminder sent as a follow-up to gather the questionnaire responses the second time round. The number of questionnaires that were returned and completed was 269, representing $71.73 \%$, which was more than $20 \%$ and thus indicating that the response rate in this research was acceptable $[4,5]$.

\subsection{Research tools creation process}

The tools used to collect data were questionnaires created according to the objectives and conceptual framework established for this study. The quality of the tool was examined for -

1) Content validity: by having 3 experts checking the consistency between the questions and objectives and the content of the study. The IOC (Index of item Objective Congruence) were found to be between $.6-1.0$ which mean all the questions were valid could be used for all questions.

2) Reliability of the tools was assessed by finding the Cronbarch's alpha coefficient $d$ which were found to be between 0.83-0.93.

\subsection{Data collection procedure}

The following steps and methods were followed:

1) Sent an official letter from Suan Sunandha Rajabhat University to ask for courtesy in collecting information of small and medium-sized enterprises in Thailand.

2) Sent questionnaire to small and medium-sized enterprises in Thailand via postal service by specifying the time to return it was within 20 days. At first, a total of 182 questionnaires were answered and returned, accounting for 48.53 percent.

3) Another official letter from Suan Sunandha Rajabhat University was sent to followup on the questionnaire response for SMEs that had not responded yet by requesting a courtesy response within 15 days. In the second round, 87 questionnaires were returned and resulted in 269 questionnaires returned in total, accounting for 71.73 percent.

\subsection{Steps for analysing data and using statistics}

- Analysis of general data of entrepreneurs and their business using descriptive statistics such as frequency and percentage.

- Analysis of human resource management and increase in productivity by using descriptive statistics such as mean and standard deviation, by presenting the data in the form of tables together with the description and conclusion of the research results

- Test the relationship of human resource management and productivity improvement of small and medium-sized enterprises in Thailand by using multiple correlation analysis.

- Test the impact of human resource management (in the areas of Human Resource Recruitment, Human Resource Rewarding, Human Resource Development, and Human Resource Maintenance) towards the increase of productivity of small and medium-sized enterprises in Thailand by using Multiple Regression Analysis.

\section{Result}

According to the results of the analyses, it was found that the relationship between human resource management and the increase of productivity of small and medium enterprises in Thailand was at a relatively high level (the $\mathrm{R}$ value was between $0.61-.80$ which was 
considered to have a relatively high level of relationship and a positive relationship at the statistical significance level 0.01).

Table 2. Correlation analysis of human resource management and overall productivity increase of small and medium enterprises in Thailand (Authors' results).

\begin{tabular}{|c|c|c|c|c|c|c|}
\hline Variants & PDM & HRR & HR & HD & HM & VIF \\
\hline $\bar{X}$ & 3.92 & 3.25 & 3.65 & 3.63 & 3.65 & \\
\hline S.D. & 0.54 & 0.72 & 0.79 & 0.81 & 0.78 & \\
\hline PDM & & $0.758^{* *}$ & $0.698^{* *}$ & $0.664^{* *}$ & $0.796^{* *}$ & \\
\hline HRR & & & $0.458^{* *}$ & $0.546^{* *}$ & $0.552^{* *}$ & 2.846 \\
\hline HR & & & & $0.502^{* *}$ & $0.436^{* *}$ & 2.532 \\
\hline HD & & & & & $0.599^{* *}$ & 3.300 \\
\hline HM & & & & & 3.602 \\
\hline
\end{tabular}

$* * *$ with statistical significance at 0.1

From Table 2, it can be implied that small and medium-sized enterprises should pay more attention to human resource management which was in accordance with the Human Capital Theory, beginning with the idea that there are both quantity and quality in human resources. Whereas for the quantity of human resources, it is the number and hours of work, the quality of human resources includes skills, knowledge, ability and other factors that affect human productivity. Quality in humans can be increased by investing in humans, which is to increase human capital for themselves and by doing so will increase productivity and earn more income. Therefore, human capital is the skills and abilities that are in the person or the labor.

The results of the test of the impact of human resource management on productivity increase in small and medium-sized enterprises in Thailand were shown in Table 2.2. It was found that human resource management in the areas of Human Resource Recruitment and Human Resource Maintenance had an impact on productivity increase of small and medium-sized enterprises in the northern region of Thailand at the statistical significance level of .01. It can be implied that the practices of strategic human resource management, including selection of personnel, training, assignment of responsibility, performance evaluation, job design, and incentive compensation showed a direct impact in decreasing the loss of production and labor productivity in the electrical and electronic appliance manufacturing organizations in Thailand. However, in this research, human resource development variables did not have an effect on productivity increase, like most theory and research concepts suggested.

Table 3. Multiple regression analysis using the dependent variables to increase the overall productivity of small and medium enterprises in Thailand (authors' results).

\begin{tabular}{|c|c|c|c|c|}
\hline \multirow{2}{*}{$\begin{array}{c}\text { Human Resource } \\
\text { Management }\end{array}$} & \multicolumn{2}{|c|}{ Productivity Enhancement } & \multirow{2}{*}{ p-value } \\
\cline { 2 - 4 } & $\begin{array}{c}\text { Regression } \\
\text { Coefficients }\end{array}$ & Standard Error & & \\
\hline Constant & 1.842 & 0.089 & 20.826 & 0.000 \\
\hline $\begin{array}{c}\text { Human Resource } \\
\text { Recruitment (HRR) }\end{array}$ & 0.249 & 0.041 & 6.181 & $0.000^{* *}$ \\
\hline $\begin{array}{c}\text { Human Resource Rewarding } \\
\text { (HR) }\end{array}$ & 0.108 & 0.035 & 3.120 & $0.02^{* *}$ \\
\hline $\begin{array}{c}\text { Human Resource } \\
\text { Development (HD) }\end{array}$ & 0.081 & 0.048 & 1.957 & 0.065 \\
\hline $\begin{array}{c}\text { Human Resource } \\
\text { Maintenance (HM) }\end{array}$ & 0.328 & 0.043 & 7.851 & $0.000^{* *}$ \\
\hline \multicolumn{2}{|c|}{$\mathrm{R}=0.838$ AdjR2 $=0.698$ SEest $=0.2752 \mathrm{~F}=155.865$} & \\
\hline
\end{tabular}

$* * *$ with statistical significance at 0.1 


\section{Discussion}

It was found that the relationship between human resource management and the increase of productivity of small and medium-sized enterprises in Thailand was at a relatively high level ( $\mathrm{R}$ values ranged between 0.61 - .80). It means that; personnel and organization development that were in line with the businesses' goals, the businesses encouragement of their employees to have the opportunity to increase their knowledge, skills and experience for career advancement and promotion, and a system to protect and maintain knowledgeable and skilled human resources within the organization, all had a direct positive effect on the productivity increase of small and medium-sized enterprises in Thailand.

This finding is in accordance with the research of Guest, Michie, Conway, and Sheehan, which had studied the impact of strategic human resource services on organizational performance by using 9 human resource management practices as independent variables, including 1) recruitment and selection, 2) training and human resource development, 3) performance evaluation, 4) financial flexibility, 5) position design, 6) 2-way communication, 7) employment stability and internal staff's prioritized selection, 8) equality and unity within the organization, and 9) the quality of personnel. As for the dependent variables, they included the employee turn-over, sales per employee, and profit per employee.

Their research found that these independent variables affected the decrease in employee turn-over and also caused the company to have a significantly higher profit per employee. In addition, this research also confirmed that strategic human resource management correlates with business performance results. [7] conducted a study in the same industry but studied factors affecting productivity and found that in terms of personal factors related to engineers or supervisors, and it was found that their coaching resulted in the highest productivity increase, with weighing factor of 0.831 . Meanwhile, a funding factor that affected productivity increase was rewarding employees who have achieved their work objectives which had an impact on productivity with the weighting factor of 0.901 .

Small and medium enterprises (SMEs) would be able to develop and increase their competitiveness by giving importance to human resource management in (1) Human Resource Recruitment - with equal employment opportunities, human resource planning of recruitment and selection of employees both domestically and internationally, job design, and job analysis, (2) Human Resource Rewarding based on the performance evaluation there should be incentives, something to motivate people to work such as payment of suitable remuneration, provision of welfare, benefits, and convenience. There should be studies on the impact of human resource management on productivity increase in other industries such as textile, automotive, electrical and electronic industries, etc.

As for literature reviews and related research to increase productivity, in a study of the influence of the difficulty of goals, the rewarding and their effects on productivity and the goal engagement, it was found that daily-paid sewing workers had higher productivity after setting goals and were provided incentives in the form of money. It was also found that with difficult goals, the use of rewards could still affect the productivity increase, though the attachment towards the goals before and after the experiment remained unchanged. The difficulty of the goal did not affect the engagement in the goal but giving away rewards showed an impact on engagement. As for the employees who were able to achieve the goals, they also became committed to the goal, but the difficulty in achieving the goal did not affect their commitment to the goal. For literature review and research on human resource management and productivity increase in production-related organizations such as in the rebar industry, there was an introduction of new practice in employment. The new method included promotion of labor payment, teamwork training, flexible job design, 
safety at work, and the development of staff training which, according to this concept, can lead to success in increasing the productivity of the organization at a high level [8].

It can be implied that the increase of both productivity and profitability of the organization arise from human resource management. In addition, human resource management that focuses on empowerment and development or training also has an effect on increased productivity. As for the study of the effects of compensation range and work efficiency in an organization as measured by increased productivity, it was found that the compensation level affected the organization's productivity and the organization's performance. That means incentive to work must be created in the organization [9]. In addition, human resource management was also found to affect the performance of the organizations that used increase of productivity as a key measure of the performance of the organization [10]. studied a technology company in Taiwan and found that human resource management, including its aspects in development and training, teamwork, and human resource planning, had effects on the increase of productivity in the organization.

On the other hand, Sung, S. Y., \& Choi, J. N. [7] conducted a study on strategic human resource management of electrical and electronic appliance manufacturing organizations in Thailand, and found that the average score of the use of strategic human resource management practices was in the "high" to "highest" level in personnel management. The summary of the results of the analysis and interpretation can be summarized as follows: First, personnel selection - the sample group paid most importance to the company's variables and made a lot of effort to select the best personnel to go into the organization.

Second, the most importance was paid to the process of recruiting people with the principles of putting the right people to the right jobs. There were also considerations of the behavior and competency problems of the personnel that occurred within the organization and used them to improve the selection of personnel to a higher standard. As for the assessment of personnel selection by the relevant departments and the human resources department of the company, the company selected personnel by strictly abiding by the rules. The company always selected executive positions from internal personnel first by promoting of internal personnel in an order. However, the strategic human resource management practices showed statistically significant negative impacts on employees' entry and exit and a direct impact on the loss of production, and labor productivity with statistical significance.

This research suggested that the electrical and electronic appliance manufacturing business in Thailand should operate by using strategic human resource management in a combined manner. There should also be implementation of strategies used as guidelines in supporting such businesses, so they can recruit suitable personnel to work with the organization and be able to protect and maintain knowledgeable and capable personnel with expertise and production skills to work with the organization for a long time. These resources will also help the organization to reduce production losses and increase labor productivity [11].

In this regard, Dullayaphut, \& Untachai [12] conducted a study in the same industry but studied factors that may affect the increase of productivity. In terms of personal factors related to engineers or supervisors, it was found that their coaching resulted in the highest productivity increase, with weighing factor of 0.831 . Meanwhile, a funding factor that affected productivity increase was rewarding employees who have achieved their work objectives that had an impact on productivity with the weighting factor of 0.901 . According to study of [13]. Critical factors influencing construction productivity in Thailand.

[10] studied the impact of strategic human resource management on organizational performance by using 9 areas of practices in human resource management as independent variables including 1) recruitment and selection, 2) training and human resource development, 3) performance evaluation, 4) financial flexibility, 5) position design, 6) 2- 
way communication, 7) employment stability and internal staff's prioritized selection, 8) equality and unity within the organization, and 9) the quality of personnel.

As for the dependent variables, they included the employee turn-over, sales per employee, and profit per employee. The results of the study showed that the earliermentioned independent variables had an effect in the decrease of employee turn-over and caused the company to have a significantly higher profit per employee. In addition, this research confirms that strategic human resource management correlated with a business's performance.

\section{References}

1. S. Siriphattrasophon, Kasetsart Journal of Social Sciences (2017).

2. D. Ushakov, Actual problems of economics 1, 162 (2016).

3. P. Ueasangkomsate, A. Jangkot. Kasetsart Journal of Social Sciences 38(2) (2017).

4. B. Pungnirund, EUrASEANS 4(5), 59 (2017).

5. P. Sriboonlue, S. Puangpronpitag, Procedia Computer Science 158, 819 (2019).

6. R. Krejcie, D. Morgan, Educational and psychological measurement 30(3), 607 (1970).

7. S. Sung, J. Choi Journal of Organizational Behavior 35(6), 851 (2014).

8. V. N. Amrutha, S. N. Geetha, Journal of Cleaner Production 119131 (2019).

9. Y. Ma, Q. Zhang, H. Yin, Journal of environmental management 255, 109795 (2020).

10. A. Distanont, O. Khongmalai, R. Rassameethes, S. Distanont, Kasetsart Journal of Social Sciences 39(3), 374 (2018).

11. T. Charoenrat, C. Harvie, Y. Amornkitvikai. Journal of Asian Economics 27, 42 (2013).

12. P. Dullayaphut, S. Untachai, Procedia-Social and Behavioral Sciences 88, 61 (2013).

13.A. Makulsawatudom, M. Emsley, K. Sinthawanarong, The journal of KMITNB 14(3), 1 (2004). 